\title{
First record of the Devonian lycophyte Leclercqia from South America
}

\author{
CHRISTOPHER M. BERRY
}

Department of Geology, University of Wales College of Cardiff, P.O. Box 914, Cardiff CF1 3YE, Wales, UK

(Received 6 September 1993; accepted 30 November 1993)

\begin{abstract}
A single leafy stem from the Middle or lowermost Upper Devonian Campo Chico Formation, Sierra de Perijá, western Venezuela, is the first record of the important Devonian herbaceous lycophyte Leclercqia from South America, usually considered as part of western Gondwana. The seemingly cosmopolitan distribution of this genus is discussed in relation to coeval assemblages and palaeocontinental reconstructions.
\end{abstract}

\section{Introduction}

The Lower Member of the Campo Chico Formation, which outcrops in the extreme west of Venezuela, has yielded the most diverse flora yet known from the Devonian of the southern continents (Edwards \& Benedetto, 1985; Berry, Casas \& Moody, 1993). Plants known from this formation include zosterophylls, ?trimerophytes, progymnosperms and cladoxylaleans. However, at certain horizons, herbaceous lycophytes dominate assemblages. Haskinsia sagittata and

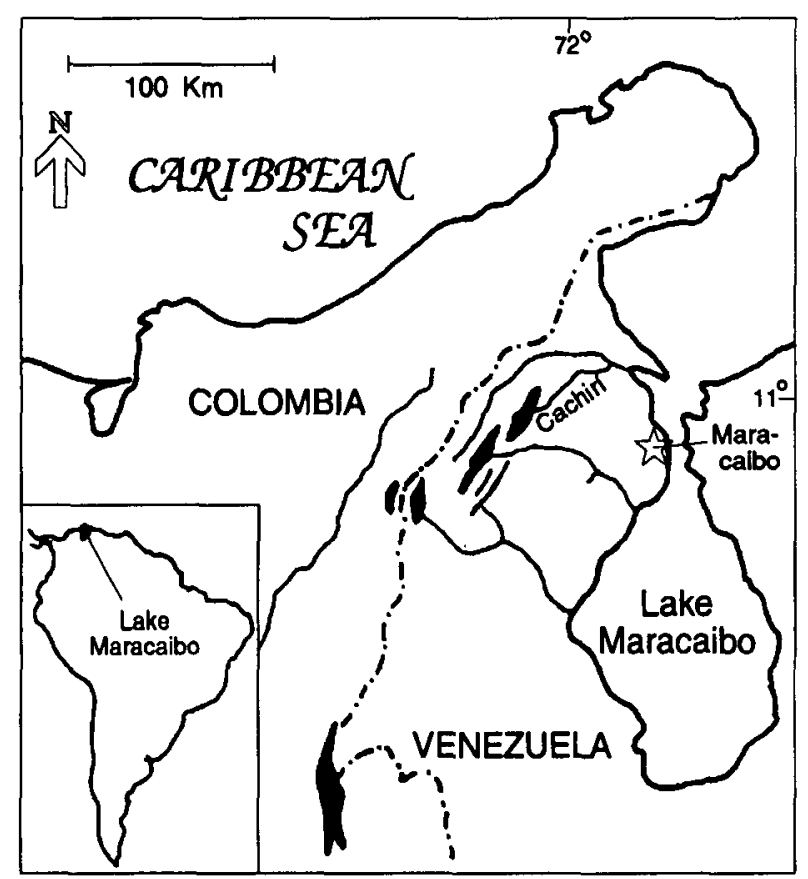

Figure 1. Devonian outcrops on the western Venezuela/ Colombia border (black). Fieldwork area located in the northernmost inlier, close to the headwaters of Rio Cachirí.
Colpodexylon cachiriense have been previously described (Edwards \& Benedetto, 1985) and a number of further species of these genera and of Archaeosigillaria and Lycopodites await publication. This paper is concerned with Leclercqia Banks, Bonamo and Grierson, the most completely known Devonian lycophyte.

\section{Locality and stratigraphy}

The Campo Chico Formation outcrops in the Caño Colorado/Rio Cachiri/Rio Pescado area of the Sierra de Perijá, Zulia State, close to the Colombian border in the extreme west of Venezuela (Fig. 1). The geology of the eleven plant-bearing horizons has recently been reviewed (Berry, Casas \& Moody, 1993). The Leclercqia specimen was collected from locality 4 (Fig. 2), located in the east gutter of the new road to Río Socuy at the first corner some

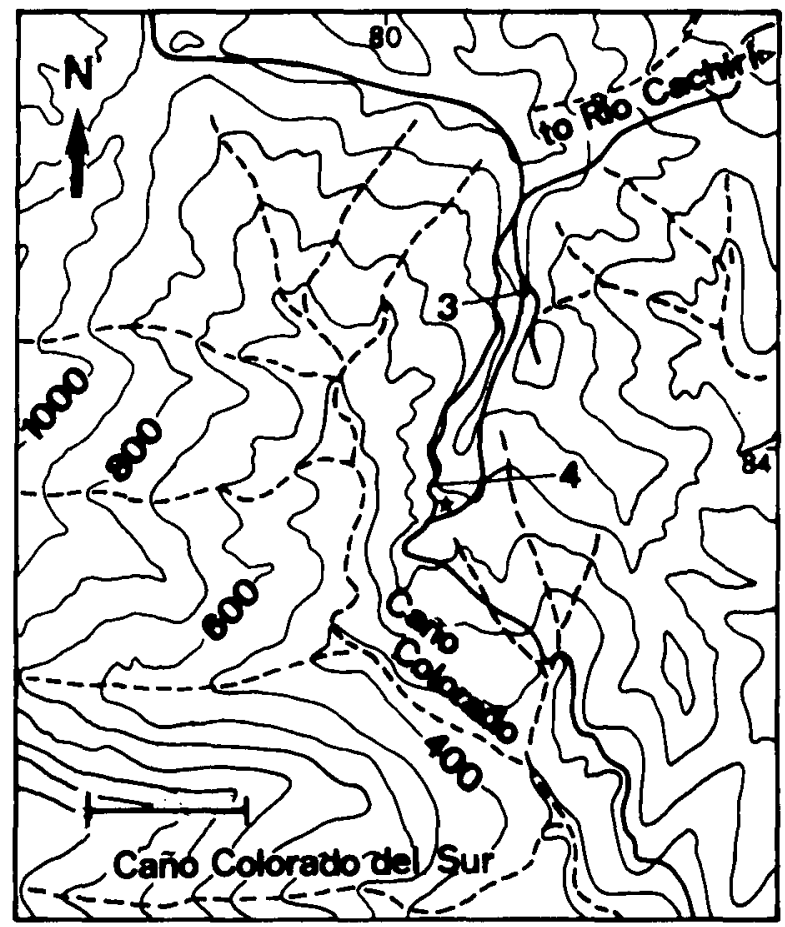

Figure 2. Topographic map showing Leclercqia locality (4) and probable northern locality of Edwards \& Benedetto, 1985 (3), Caño Colorado, Zulia State, western Venezuela. Dashed lines $=$ streams and rivers, unbroken lines $=$ tracks, star $=$ hacienda 'El Reposo'. Heights in metres; scale bar = $1 \mathrm{~km}$. 

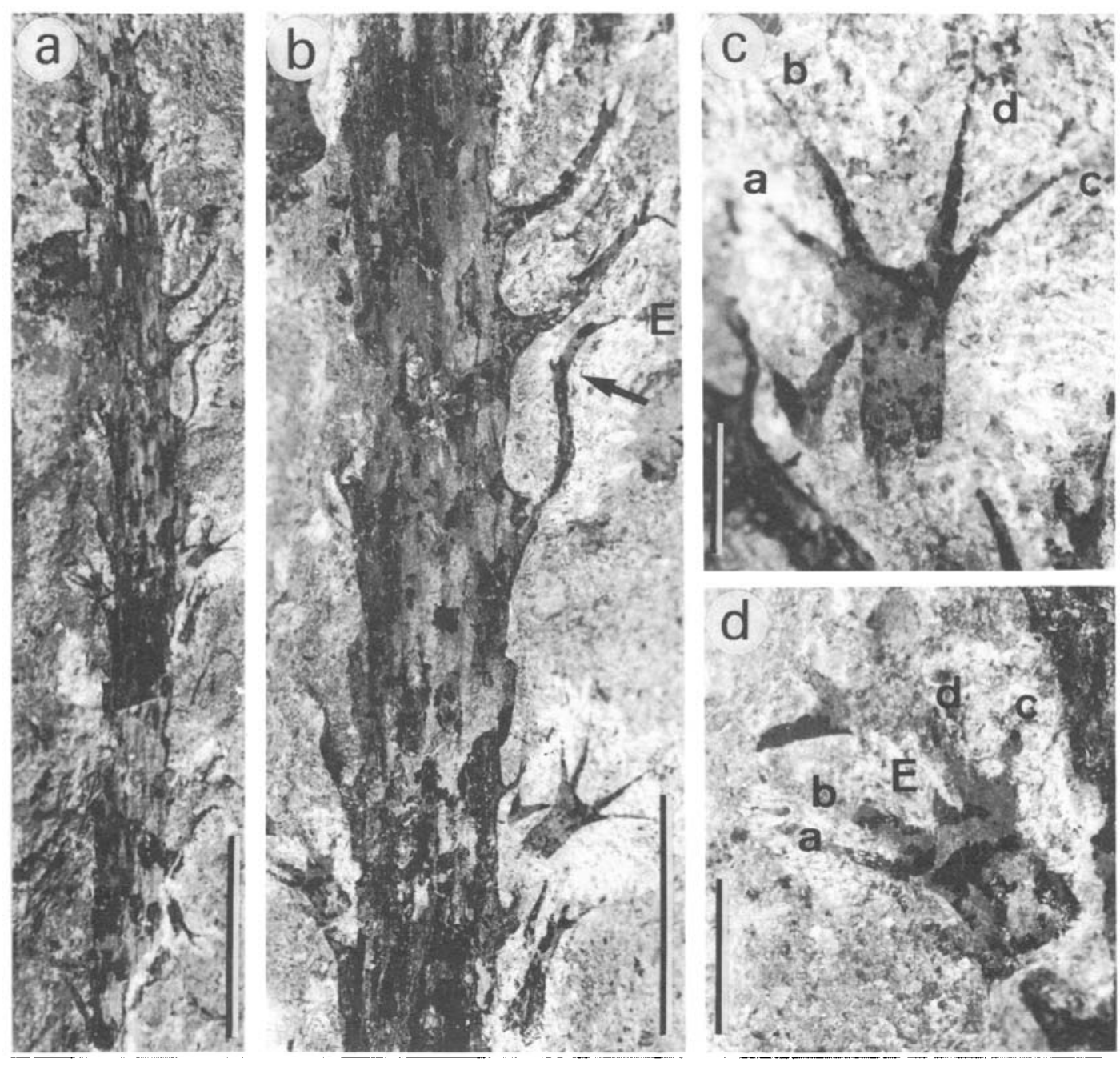

Figure 3. Leclercqia cf. complexa. Specimen no. NMW 93.97G.1b: (a) view of preserved stem; (b) close-up of stem surface showing longitudinal ridges along compression surface and divided leaves; (c, d) divided leaves, lettering of segments follows Fairon-Demaret (1980). Scale bars (a) $=10 \mathrm{~mm},(b)=5 \mathrm{~mm},(c, d)=1 \mathrm{~mm}$.

$200 \mathrm{~m}$ north of the entrance to the hacienda 'El Reposo'. Other fossils from this horizon include abundant sterile axes of 'Taeniocrada', enigmatic fertile axes and rare specimens of Haskinsia sagittata. Poorly preserved palynomorphs from the matrix at this horizon suggest an early Givetian or late Eifelian age (J. B. Richardson, pers. comm.), but the evidence from plant megafossils and invertebrates summarized by Berry, Casas \& Moody (1993) suggests that even an earliest Late Devonian age cannot be ruled out. The specimen is deposited in the National Museum of Wales, Cardiff, as specimen no. NMW 93.97G.1 a \& b.

\section{Description}

Both part and counterpart of a single sterile unbranched stem, preserved as a coalified compression in a dark grey mudstone matrix, were collected. The stem is $75 \mathrm{~mm}$ long and $3.3 \mathrm{~mm}$ wide (Fig. $3 \mathrm{a}$ ). Leaves are persistent and attached in an upwards parastichy of about $30^{\circ}$, there being 9 or 10 leaves per gyre. Leaves in successive gyres alternate. On impression surfaces, low longitudinal ridges can be seen curving around successive leaf attachments to form a fusiform pattern (Fig. 3b). The leaves are attached at the middle of longitudinally elongate mounds delimited by the fusiform pattern. Leaves seen on the fracture plane show an abaxially recurved tip (Fig. $3 \mathrm{~b}, \mathrm{E}$ ) distal to a division (arrowed), or a division to form two or more segments (Fig. 4). However, uncovering reveals a broad lamina 0.48$0.70 \mathrm{~mm}$ wide which divides $2.8-3.6 \mathrm{~mm}$ from the base. The long central segment (up to at least $2.7 \mathrm{~mm}$ long) recurves abaxially and thus is not always visible (Fig. 3c). On each side of the branching point two short lateral laminae are seen, and these immediately divide into two slender segments at least $1.8 \mathrm{~mm}$ long. These four lateral segments are orientated in a variety of ways, but the arrangement of the five segments is always in three dimensions (note the differing planes of focus of the four lateral segments in Fig. $3 \mathrm{c}$ ). In one leaf it is possible to see clearly the proximal ends of all five segments (Fig. $3 \mathrm{~d}$ ).

\section{Discussion \\ 4.a. Identity}

On the basis of its five-tipped leaves, this plant is assigned to the genus Leclercqia, known best from the type species $L$. complexa Banks, Bonamo \& Grierson, 1972, from the Panther Mountain Formation, Tioughniogan Stage, Erian Series, Middle Devonian of New York State, USA. More recent papers on plants from the type locality (Grierson, 1976; Grierson \& Bonamo, 1979; Bonamo, Banks \& 


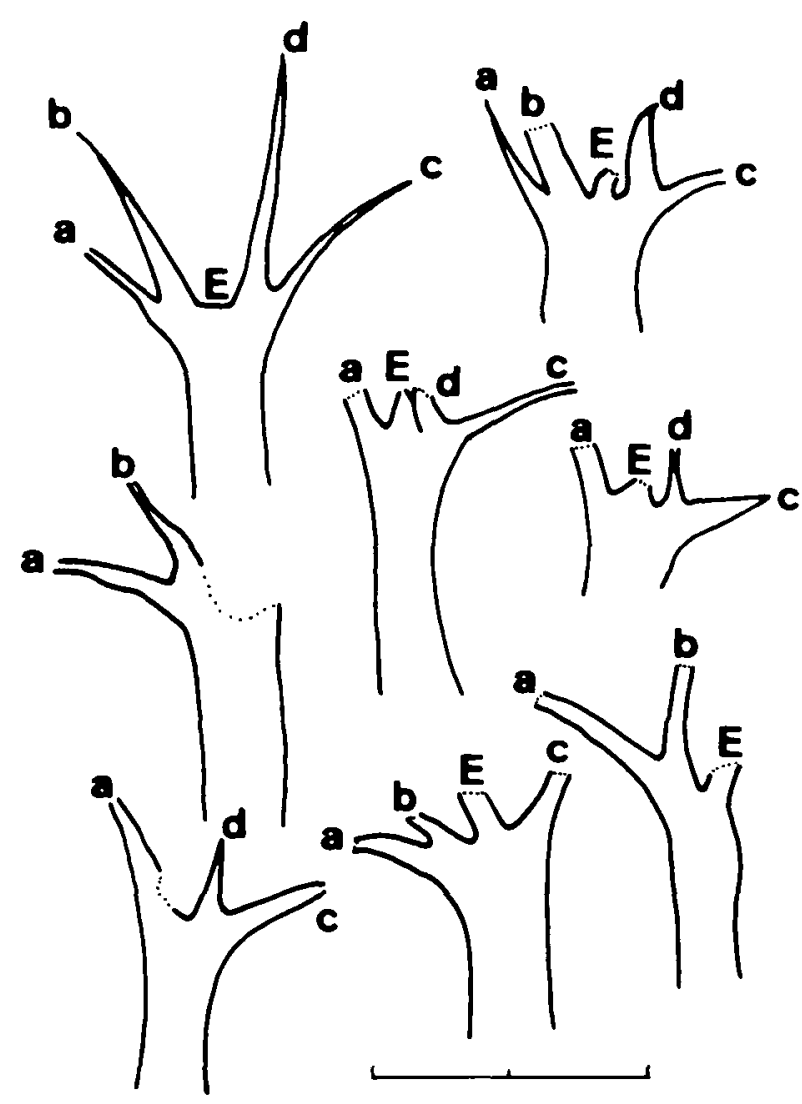

Figure 4. Leclercqia cf. complexa. Specimen no. NMW 93.97G.1. Outlines of leaves drawn from camera lucida. Lettering as Figure 3. Scale bar $=2 \mathrm{~mm}$.

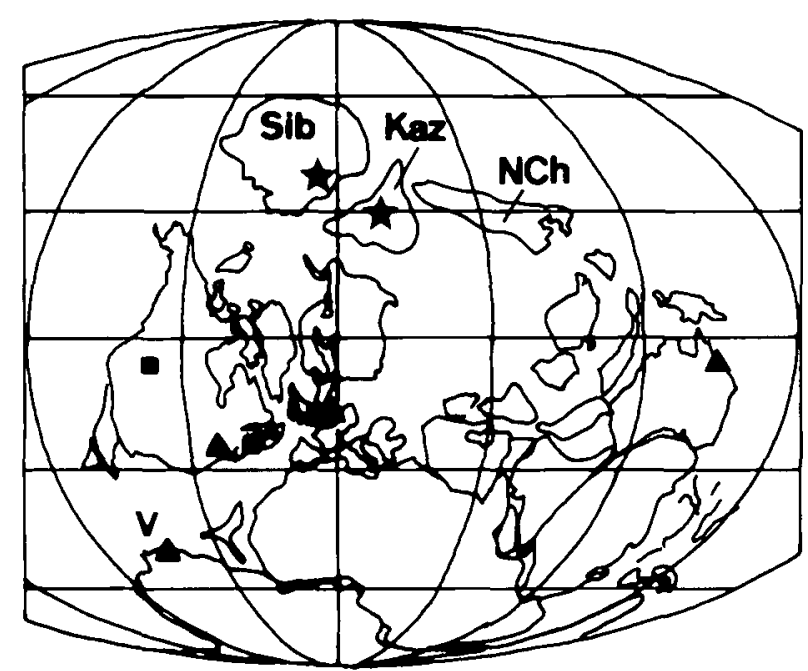

Figure 5. World-wide distribution of Leclercqia plotted on the Givetian map of Scotese \& McKerrow (1990). Triangles $=$ Middle/lowermost Upper Devonian, squares $=$ lower Devonian, star $=$ unconfirmed, $V=$ Venezuelan locality, $\mathrm{NCh}=$ north China, Sib $=$ Siberia, $\mathrm{Kaz}=$ Kazakhstan.

Grierson, 1988) show that more is known about the morphology and anatomy of $L$. complexa than any other Devonian lycophyte.

The present specimen compares very closely with those of L. complexa from New York State, and is only different in the slightly narrower stem (3.5-7 mm reported for NYS).
Measurements of isolated leaves in the collections of SUNY$B$ from the type locality suggests that lamina width may reach $0.93 \mathrm{~mm}$ before the trifurcation, although the average is considerably less. Hence the leaves of the Venezuelan specimen, although few in number, are thought to be essentially identical to those from the type collection. However, because it is not possible to demonstrate a ligule, sporophylls, sporangia, spores or anatomy, the specimen is referred to Leclercqia cf. complexa, the most realistic designation for a plant which is morphologically identical to sterile specimens from the type locality but lacks the additional diagnostic fertile characters.

Kasper (1977) briefly reported a new species of Leclercqia, in which the central segment of the leaf curved upwards, from the Emsian of New Brunswick, but which was not given a new name. Kasper \& Forbes (1979) assigned new plants from the Trout Valley Formation of Maine to $L$. complexa on account of their five-divided leaves. However, these leaves are planate and arranged with the five segments looking like a dinner fork rather than in the threedimensional arrangement of the type material, and it is therefore more realistic to consider these plants as a further new species. These two records are clearly different from both the type material and the Venezuelan specimen.

\section{4.b. Distribution}

Since 1972 a number of taxa previously assigned to Protolepidodendron Krejci have been reassigned to Leclercqia. Bonamo, Banks \& Grierson (1988) discussed in detail the confusion between the genera Protolepidodendron and Leclercqia.

Fairon-Demaret (1974) showed that stems from the Middle or lowermost Upper Devonian Burdekin Basin of Queensland, Australia, previously assigned to Dicranophyllum australicum Dawson and Protolepidodendron scharyanum (Kräusel \& Weyland, 1940), have leaves with five segments and are in other respects similar to Leclercqia. She also (1980) showed that fertile leaves from stems from the Givetian of Germany (Kräusel \& Weyland, 1932) possessed leaves with five segments rather than the once dichtomous leaves reported for the type specimen of P. scharyanum (Krejci, 1880) from Bohemia. Leaves from the German specimens seemed to fit almost exactly the dimensions of $L$. complexa from New York State. Finally (1981) she showed that specimens from Ronquières (late Givetian) and Oé (Middle Devonian) from Belgium also shared the characteristics of the leaf of Leclercqia. The specimens from Oé were designated Leclercqia $\mathrm{cf}$. complexa (on account of the slightly different arrangement and dimensions of the leaf tips), and those from Ronquières, L. complexa.

Tanner (1984) reported new fertile specimens of Leclercqia from the Lower Devonian Beartooth Butte Formation in northern Wyoming, USA.

Other possible records include Ananiev's (1960) Protolepidodendron scharyanum from the Givetian of the AltaiSayan mountains, Siberia. His illustrations show small lycophytes with typical protolepidodendrid stems and divided leaves. The leaves are never seen to branch more than once but the exposed segments are usually irregular and not symmetrical. Usually the longest segment is abaxially recurved and the shorter segment points upwards (distally). This is exactly the appearance of Leclercqia leaves when exposed on a fracture surface before preparation, and is unlike the appearance of any other known lycophyte. 
Similarly specimens of $P$. scharyanum from Kazakhstan (Senkevich, 1961) bear a striking resemblance to unprepared Leclercqia. Other occurrences of $P$. scharyanum should also be regarded critically. A fine example is the transfer of Chinese specimens to the new genus Minarodendron by $\mathrm{Li}$ (1990) on account of their unique leaf morphology and distinct xylem ultrastructure.

Leclercqia is therefore known from North America, Europe, Australia and South America and perhaps farther afield. Given the lack of consensus of a palaeogeography for the Devonian (Berry, Casas \& Moody, 1993), the distribution is plotted on the most recently published Givetian reconstruction of Scotese \& McKerrow (1990) (Fig. 5). The significance of the Venezuelan occurrence is that it demonstrates the presence of Leclercqia in a locality currently considered to be part of western Gondwana. This genus may have been distributed along the northern margin of Gondwana as well as much of Laurussia (Euramerica). Due to uncertainty of the exact dating of the majority of the occurrences it is impossible to comment further on possible changes in the distribution of the plant with time. However, the cosmopolitan nature of this plant adds weight to the concept of a single world-wide palaeokingdom during Middle Devonian times (Meyen, 1987; Edwards \& Berry, 1991).

\section{4.c. South American lycophytes}

The sparse previous records of Devonian herbaceous lycophytes from Gondwana have been reviewed by Edwards \& Benedetto (1985). No other Devonian lycophytes with such complexely divided leaves are known from South America. Recently herbaceous lycophytes from the Carboniferous of Argentina have been placed in a new taxon Frenguellia eximia (Frenguelli) Arrondo, Cesari \& Gutierrez (1991). Some of these specimens are illustrated as having five-tipped leaves with division between half and two-thirds of their total length (up to $4.5 \mathrm{~mm}$ ). Justification for the assignment of these plants to the new genus Frenguellia was so as not to indulge in the 'unacceptable procedure' of putting the abundant Argentinian material into a well defined genus such as Leclercqia given the small differences in the size of the leaf, the unproven location of the sporangia, and the lack of an abaxially recurved medial segment. Therefore this material has not yet been excluded from being very closely related to Leclercqia, but is not considered well enough preserved to make a reliable comparison. However, Arrondo, Cesari \& Guiterrez 'regard the combination of these perhaps preservational differences as gaining support from the geographic separation of the Devonian Leclercqia from the Carboniferous Gondwanic Frenguellia' (p. 195). In the light of similarities of Venezuelan and North American Devonian assemblages (Berry, Casas \& Moody, 1993) and the world-wide occurrence of Leclercqia geographic separation is no longer such a valid reason for such a decision. Better preserved fertile material is required to make a more detailed comparison of Frenguellia with Leclercqia.

Acknowledgements. I thank Maraven S.A. for funding fieldwork in the Sierra de Perijá, and the assistance of Jhonny Casas. Western Atlas Core Laboratories allowed John Moody to participate in fieldwork. Professor Patricia Bonamo (SUNY - Binghamton) kindly allowed access to the Gilboa material. This research was financed by NERC grant no. GR/4/89/GS/120. The supervision of Professor Dianne Edwards is warmly acknowledged.

\section{References}

ANaniev, A. R. 1960. Studies on the Middle Devonian flora of the Altai-Sayan mountain region. Botanicheskii Zhurnal 45, 649-66 (in Russian with English summary).

Arrondo, O., Cesari, S. N. \& Gutierrez, P. R. 1991. Frenguellia, a new genus of lycopods from the Early Carboniferous of Argentina. Review of Palaeobotany and Palynology 70, 187-97.

Banks, H. P., Bonamo, P. M. \& Grierson, J. D. 1972. Leclercqia complexa gen. et sp. nov., a new lycopod from the late Middle Devonian of eastern New York. Review of Palaeobotany and Palynology 14, 19-40.

Berry, C. M., Casas, J. E. \& Moody, J. M. 1993. Diverse Devonian plant assemblages from Venezuela. Documents des Laboratoires de Géologie, Lyon 125, 29-42.

Bonamo, P. M., Banks, H. P. \& Grierson, J. D. 1988. Leclercqia, Haskinsia, and the role of leaves in delineation of Devonian lycopod genera. Botanical Gazette 149, 222-39.

EDWARDS, D. \& BenedeTto, J.-L. 1985. Two new species of herbaceous lycopods from the Devonian of Venezuela with comments on their taphonomy. Palaeontology 28, 599-618.

EDWARDS, D. \& BERRY, C. M. 1991. Silurian and Devonian. In Plant Fossils in Geological Investigation: the Palaeozoic (ed. C. J. Cleal), pp. 117-53. Chichester: Ellis Horwood.

FaIron-Demaret, M. 1974. Nouveaux specimens du genre Leclercqia Banks, H. P., Bonamo, P. M. et Grierson, J. D. 1972 du Givetian (?) du Queensland (Australie). Bulletin de IInstitut Royal des Sciences Naturelles de Belgique 50, 1-4.

FaIRon-Demaret, M. 1980. A propos des spécimens déterminés Protolepidodendron scharianum par Kräusel et Weyland, 1932. Review of Palaeobotany and Palynology 29, 201-20.

FaIRoN-Demaret, M. 1981. Le genre Leclercqia Banks, H. P., Bonamo, P. M. et Grierson, J. D. 1972 dans le Devonien Moyen de Belgique. Bulletin de IInstitut Royal des Sciences Naturelles de Belgique 31-XII, 1-10.

Grierson, J. D. 1976. Leclercqia complexa (Lycopsida, Middle Devonian): its anatomy, and the interpretation of pyrite petrifactions. American Journal of Botany 63, 1184-202.

Grierson, J. D. \& Bonamo, P. M. 1979. Leclercqia complexa: earliest ligulate lycopod (Middle Devonian). American Journal of Botany 66, 474-6.

KASPER, A. E. 1977. A new species of the Devonian lycopod genus Leclercqia from New Brunswick, Canada. American Journal of Botany, Publication no. 154, p. 39 (abstract).

Kasper, A. E. \& Forbes, W. H. 1979. The Devonian lycopod Leclercqia from the Trout Valley Formation in Maine. Maine Geology Bulletin (Geology Society of Maine) 1, 49-59.

Kräúsel, R. \& WEYland, H. 1932. Pflanzenreste aus dem Devon. IV. Protolepidodendron Krejci. Senkenbergiana 14, 391-403.

KräUSEl, R. \& WeYland, H. 1940. Pflanzenreste aus dem Devon. XII. Die Gattung Protolepidodendron Krejci. Senkenbergiana 20, 6-16.

KrEjCl, J. 1880. Notiz über die Reste von Landpflanzen in der Böhmischen Silurformation. Königliche Böhmische Gesellschaft der Wissenschaften in Prague, Sitzungberichte Jahrgang, 1879, 201-4.

Li, Cheng-Sen. 1990. Minarodendron cathaysiense (gen. et comb. nov.), a lycopod from the late Middle Devonian of Yunnan, China. Palaeontographica Abteiling B 220, 97-117.

MeyEN, S. V. 1987. Fundamentals of Palaeobotany. London: Chapman and Hall. 432 pp.

Scotese, C. R. \& MCKerrow, W. S. 1990. Revised world maps and introduction. In Palaeozoic Palaeogeography and Biogeography (eds W.S. McKerrow and C. R. Scotese), pp. 1-21. Geological Society Memoir no. 12.

SENKEVICH, M. A. 1961. Opisanie flory devona Kazakhstana. Ministerstvo Geologii i Okhrana Nedr Kazakhstoy S.S.S.R., Youjno-Kazakhst. Geol Ouprav. Moska 26, 115-211 (in Russian).

TANNER, W. R. 1984. A fossil flora from the Beartooth Butte Formation of Northern Wyoming. In Dissertation Abstracts International 44, no. 7, 1984. 